\title{
ロック材料の三軸試験およびねじり単純せん断 試験による非排水動的強度
}

\author{
松本 徳久 $1 \cdot$ 安田 成夫 $2 \cdot$ 芳岡 良一 3 \\ 1 正会員 工博 (財)ダム技術センター 技術第一部（テ106 東京都港区麻布台 2-4-5 メソニック 39 森ビル 7F) \\ 2 正会員 博 (工) 建設省土木研究所 企画部企画課長 (テ305つくば市大字旭一番地) \\ 3 正会員 工修 清水建設(株) 北海道支店 土木部美生ダム作業所（テ082-03 北海道河西郡芽室町字上美生） \\ （前 建設省土木研究所 ダム部フィルダム研究室 交流研究員）
}

\begin{abstract}
本論文は, フィルダム堤体材料の室内試験によるせん断強度の求め方について整理し, ロック材料を用いた単 調載荷試験と繰返し載荷試験結果を示し, ロック材料の動的強度特性に対する諸要因（繰返し回数, ひずみ量, 相 対密度, 初期拘束圧, 初期せん断応力) の影響を調べ, 静的強度と動的強度の関連性を検討した. 非排水綝返し載 荷試験では, 繰返し回数の增加に伴いひずみが增大し, 間隙水圧は $90 \%$ 100\%近くまで急激に上昇するが, 液状 化のような flow failure は起こらない. なおロック材料の単純せん断試験は国内外を通じて他に例がない. 以上の ことから, ロックフィルダムの耐震設計に用いるベきロック材料の強度特性を明らかにした. 一方, ねじり単純せ ん断試験による繰返しせん断応力比は平均主応力・初期せん断応力の大きさによらず三軸試験のそれよりも小さい.
\end{abstract}

Key Words: rockfill materials, large-scale triaxial test, large-scale torsional simple shear test, cyclic loading, monotonic loading, undrained strength

\section{1. はじめに}

フィルダムは, 大きく分類すると土質材料を主体とす るアースフィルダムと岩石質材料を主体とするロック フィルダムからなる.アースフィルダムでは, 地震時に 基礎あるいは堤体に液状化を生じた例がある. 堤体その ものの液状化による被害としては，1971 年 San Fernando 地震における Lower San Fernando ダムが あげられる 1). 本ダムは，重機による締固めがなされず， 堤体材料を水と一緒にパイプ内を運搬する方法である 水締め工法を採用している.したがって，堤体材料の粒 子の大きさは送水管の内径と送水量により制約を受け る. また, 締固めがなされていないため, 堤体材料の密 度は低い状態にある。

一方, ロックフィルダムは, 1850 年代のカリフォル ニアに端緒をなすとされるが, 液状化のような被害は出 していない. 我が国でロックフィルダムが築造されたの は 1950 年代の後半からで, 以来およそ 200 のロックフ イルダムが建設された. 建設当初は耐震性が危惧された が 1964 年の新潟地震から 1995 年の兵庫県南部地震に 至るまで, 亀裂程度の軽微な被害はあっても決壊のよう な重大な被害は生じていない。耐震設計の実務では震度 法が使われており ${ }^{2)}$, 既往の地震に対してロックフィル ダムが満足すべき挙動を示してきたということは, 震度
法が設計法としての役割を果たしてきたと言える.しか し震度法は地震荷重を堤高方向に一定としていること および堤体材料の強度として静的強度を用いており, 耐 震設計上高度化すべき課題もあり, 地震荷重については 他の報文 3 に譲るとして, 本報文ではロックフィル材料 の動的強度特性を明らかにし, 動的強度と静的強度の関 係も整理した. すなわち, よく締固められたロック材料 について繰返し載荷試験結果を示し,ロック材料の動的 強度特性に関する諸要因 (繰返し回数, ひずみ量, 相対 密度, 初期拘束圧, 初期せん断応力) の影響をとりまと めた.これらの結果は修正震度法によるロックフィルダ ムの耐震設計指針(案)4)に採り入れられた。

\section{2. 供試体作製条件およひ試験手順}

試験に用いた試料は, 三国川ダムのロック原石山から 採取して運搬してきたものである.盛立てロックの岩質 は, 堅硬な斑れい岩である. 斑れい岩は, Fig.1 の間隙 比と締固め時間の関係に示すように供試体作製時に電 気ハンマで 300 秒程度締固め, 密度がかなり高くなった 状態で破砕率は $5 \%$ となっており, 絽返しせん断試験中 に動的強度に及ぼす粒子破砕の影響が少ない材料と言 える。

供試体は, 繰返し三軸試験では, 直径 $30 \mathrm{~cm}$ ・高さ 
Table 1 Physical properties of material.

\begin{tabular}{lll}
\hline Specific gravity & $\mathrm{G}_{\mathrm{s}}$ & 2.933 \\
\hline Water content & $\mathrm{W}$ & $0.54(\%)$ Air-dry \\
\hline Maximum void ratio & $\mathrm{e}_{\max }$ & 0.569 \\
\hline Minimum void ratio & $\mathrm{e}_{\min }$ & 0.142 \\
\hline maximum grain size & $\mathrm{D}_{\max }$ & $63.5 \mathrm{~mm}$ \\
\hline Coefficient of uniformity & $\mathrm{U}_{\mathrm{c}}$ & 30 \\
\hline Dry density of specimen & $\rho_{\mathrm{d}}$ & $2.46,2.53 \mathrm{~g} / \mathrm{cm}^{3}$ \\
\hline
\end{tabular}

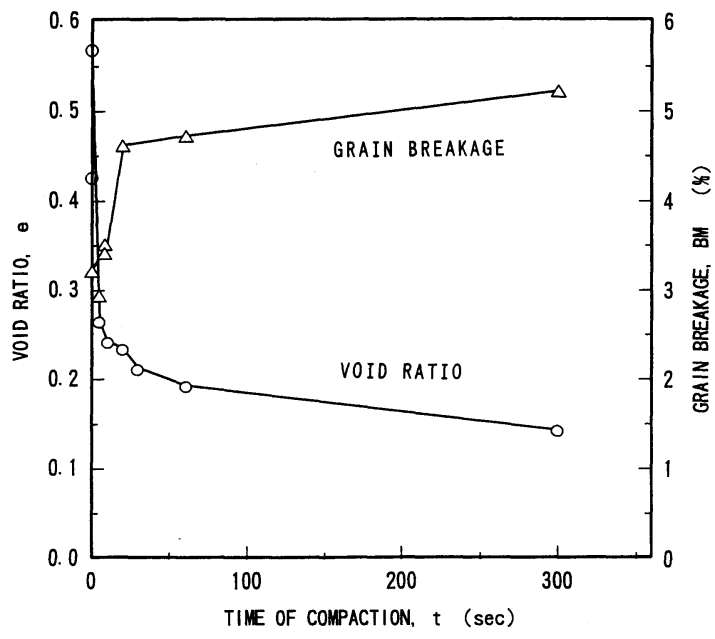

Fig.1 Void ratio and grain breakage versus compaction time relationship.

$60 \mathrm{~cm}$ である. 繰返しねじり単純せん断試験では外径 $80 \mathrm{~cm} \cdot$ 内径 $40 \mathrm{~cm}$ ・高さ $80 \mathrm{~cm}$ の中空供試体である ${ }^{5)}$. 試験材料の物性値は Table 1 に示す. 試料の粒度分布曲 線を Fig. 2 に示す.

図中の最大粒径は, 従来の単調載荷試験の最大粒径が 供試体直径の $1 / 5$ 程度とされていることを考虑して 63.5mm とした.同図には Banerjee et al. 6)が Oroville 夕゙ム堤体材料を用いて非排水の繰返し載荷試験を実施 した供試体の粒度分布曲線も示しており, 今回の試験材 料とほぼ同じ粒度分布になっている．彼らによれば， $\mathrm{D}_{50}=9.5 \mathrm{~mm}$ の材料の場合, メンブレン貫入に伴うメン ブレン・コンプライアンス比 $\mathrm{C}_{\mathrm{RM}}$ (有効拘束圧時の供試 体骨格の体積ひずみ $\varepsilon$ 、に対するメンブレン貫入量によ る体積ひずみ $\varepsilon_{\mathrm{vm}}$ の比 $\left.\varepsilon \mathrm{vm} / \varepsilon_{\mathrm{v}}\right)$ は, 0.18-0.30であ り，100\%の間隙水圧に達するときのせん断応力比の補 正は, 一律 10\%低減している.

間隙水圧測定装置によるコンプライアンスは, Banerjee et al.6)は 12 インチ直径(約 $30 \mathrm{~cm}$ )の供試体で は無視できるほど小さいと指摘しており,ここでも補正

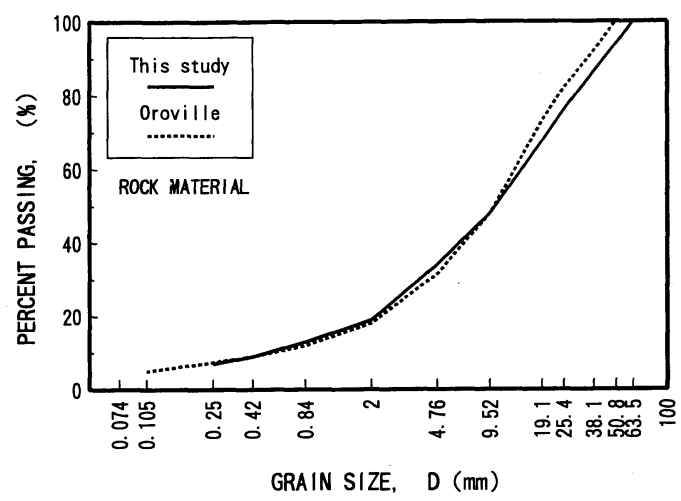

Fig.2 Grain size distribution curve.

は行わない, さらに，供試体の不飽和によるコンプライ アンスは Martin et al.7)がシリカ砂について供試体の飽 和度との関連を報告しているが, 原位置の状況を考える と Skempton のB值が 0.95 以上であれば問題がないと しており,ここでは 0.96 以上とした.

供試体は，相対密度 $\mathrm{D}_{\mathrm{r}}=60 \%, 70 \%, 85 \%, 95 \%$ の 4 種類 設定した. 直径 $30 \mathrm{~cm}$, 高さ $60 \mathrm{~cm}$ のモールドを使用し， 最大間隙比(0.569)は一定重量の材料を投入のみした際 の体積から,最小間隙比 $(0.142)$ は投入した材料の間隙比 が変化しなくなるまで電気ハンマーにより締固めた時 の体積から求めた.

繰返し載荷試験の手順は次の通りである.

(1)まず, $19.6 \mathrm{kPa}$ の真空圧で自立させていた供試体に， $19.6 \mathrm{kPa}$ の拘束圧をかけ, 真空圧を解放している.

(2)次に, 供試体間隙内に圧力 $4.9 \mathrm{kPa}$ の二酸化炭素を 24 時間通して空気と置換する.これは, 二酸化炭素が 空気と比べはるかに水に溶けやすい性質を利用して, 供 試体の飽和度を高めるためである.

(3)置換が終了したなら, あらかじめ用意しておいた供 試体の空隙 3 本分の脱気水をやはり 24 時間通し供試体 を飽和させる。

(4)飽和度は, Skempton のB係数によりチェックし, B係数が 0.96 以上の供試体を試験に用いた。

(5)圧密は,圧密時の体積変化量が $0.05 \% / \mathrm{min}$ 以下に なったら終了し, 繰返し載荷試験を開始する. 圧密には 平均約 45 分要した.

試験は荷重振幅制御により周波数 $0.1 \mathrm{~Hz}$ の正弦波で 非排水条件で行った. なお供試体には, $0.2 \mathrm{MPa}$ の背圧 を作用させた. 繰返し載荷試験は, 各試験条件について 繰返しせん断応力比を変えて $3 \sim 4$ 試験実施している. また, 三軸試験装置の制限により，両振幅軸ひずみ $10 \%$ または繰返し回数 100 をもって試験の終了条件とした. 試験データは, $1.0 \mathrm{~Hz}$ のローパスフィルターをかけて ノイズを消去している. その後デジタル変換し, パーソ 

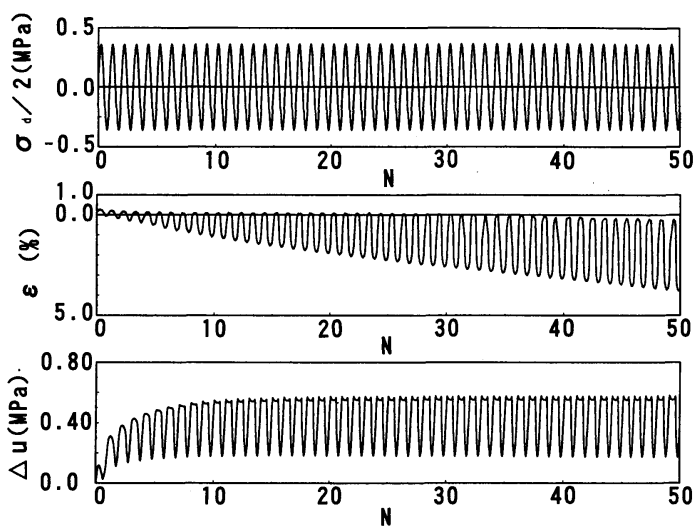

Fig.3 Time histories of deviator stress, axial strain and porewater pressure at cyclic triaxial tests under undrained isotropic consolidation condition $\left(\mathrm{Dr}=85 \%, \sigma_{\mathrm{m}}^{\prime}=0.1 \mathrm{MPa}, \sigma_{1}^{\prime} / \sigma_{3}^{\prime}=1.0\right)$.

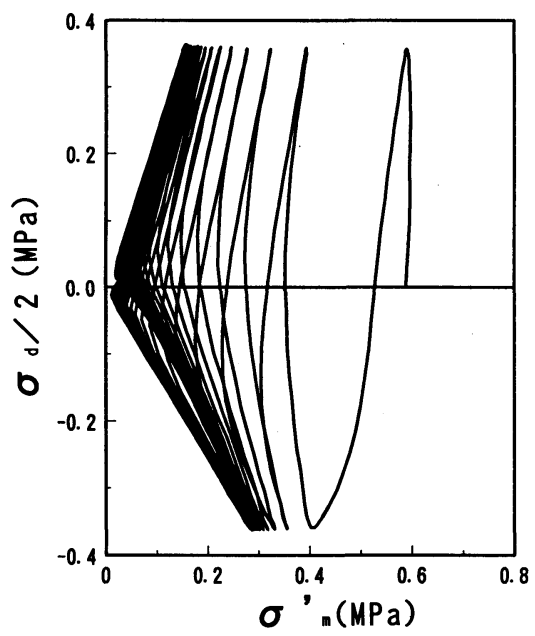

Fig.4 Stress path of rockfill materials at cyclic loading test under undrained isotropic consolidation condition.

ナルコンピュータを介してプロッターにより図化を行 った.

\section{3. ロック材料の動的強度}

ロックフィルダムは堤体の大部分を粗粒材料が占め ており, 過去に地震によって亀裂程度の軽微な被害はあ つても破壊に至るような大きな被害を受けたことはな い. 充分に締固められた粗粒材料では, 密度が高く粒子 間のかみ合せが良好なこと，その排水性が良いことなど から一般に地震荷重に対して液状化を起さないと考え られている。一方, 密な砂では, 繰返し載荷によって間

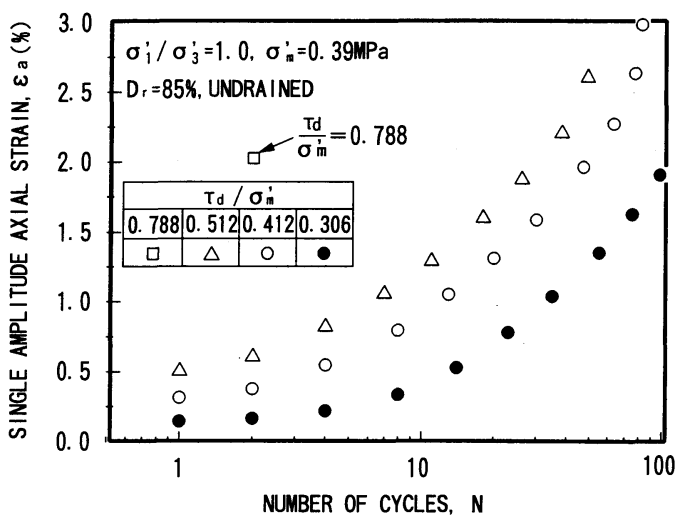

(a) $\left(\sigma_{1}^{\prime} / \sigma_{3}^{\prime}=1.0\right)$.

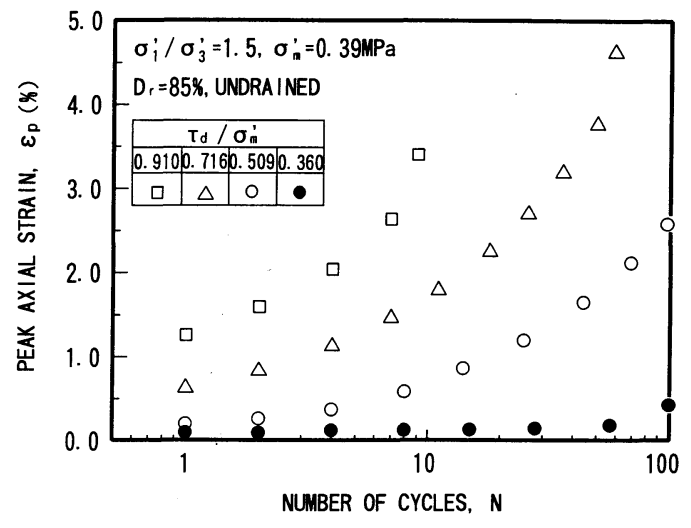

(b) $\left(\sigma^{\prime}{ }_{1} / \sigma^{\prime}{ }_{3}=1.5\right)$.

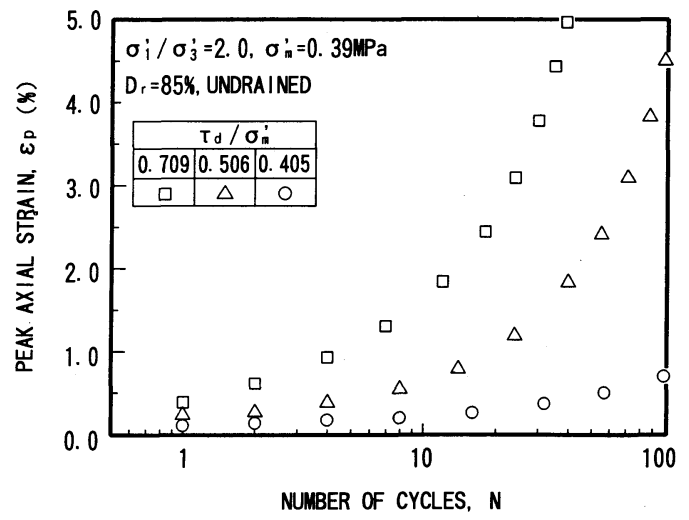

(c) $\left(\sigma^{\prime}{ }_{1} / \sigma^{\prime}{ }_{3}=2.0\right)$.

Fig.5 Single axial strain versus number of cyclic loading relationship at undrained cyclic loading test under isotropic consolidation condition.

隙水圧が上昇しひずみが累積するが, 流動を起さずに Cyclic Mobility ${ }^{8)}$ 状態となる. 密な粗粒材料についても 密な砂と同様の挙動を呈すると考えられる.すなわち, 相対密度にしておおよそ 85\%以上で施工されるロック フィルダムのロック材料では, 繰返し載荷試験中に過剩 


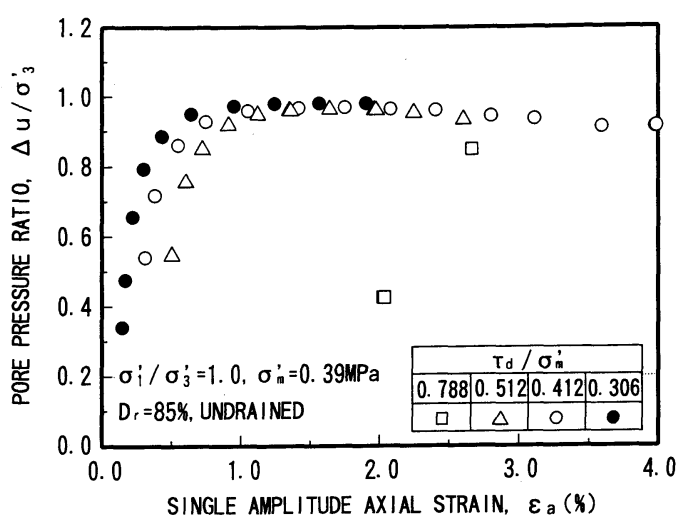

(a) $\left(\sigma^{\prime}{ }_{1} / \sigma_{3}^{\prime}=1.0\right)$.

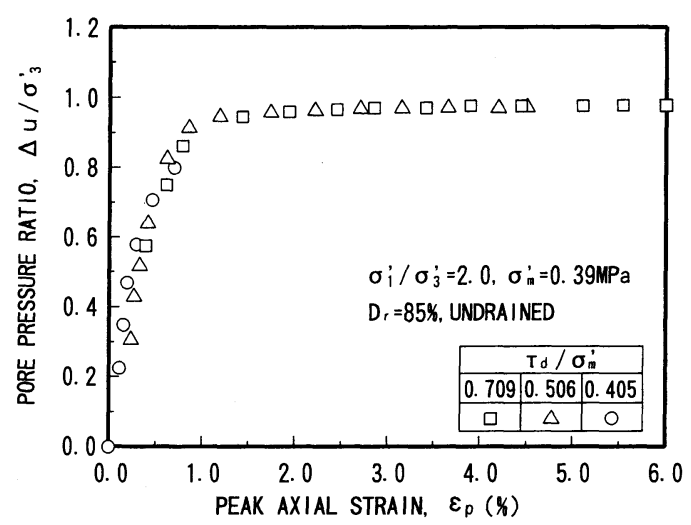

(b) $\left(\sigma_{1}^{\prime} / \sigma^{\prime}=2.0\right)$.

Fig.6 Porewater pressure versus single axial strain relationship at undrained cyclic loading test under isotropic condition.

間隙水圧が発生し, 有効応力が 0 になっても流動化する ことがない. その際にひずみはゆっくりと累積するとこ ろの Cyclic Mobility 状態となる.このような材料の動 的強度は, 流動化を伴う液状化強度とは異なるが, 一般 に絽返し回数と発生が予想されるひずみに着目し求め られ, 本研究でもこれに沿った整理を行っている.

非排水の繰返し載荷試験において, 繰返し回数は, 制 御に用いられる荷重の 1 周期を 1 回と数え， $\mathrm{N}$ 周期を $\mathrm{N}$ 回とする.また, 所定の軸ひずみが生じたときの絽返 し回数 $\mathrm{N}$ は地盤工学会基準「土の繰返し非排水三軸試 験方法」(T541)9)に準じて算定した。

\section{（1）繰返し三軸試験によるロック材料の動的強度}

繰返し載荷時の累積ひずみの定義は, 初期せん断応力 の有無により累積のし易さが異なるから, 等方圧密と異 方圧密では定義を変えている.すなわち, 等方圧密状態 では両振幅ひずみを半分にした片振幅ひずみで, 異方圧 密状態では,ひずみ振幅がほぼ一定で圧縮の方向にひず

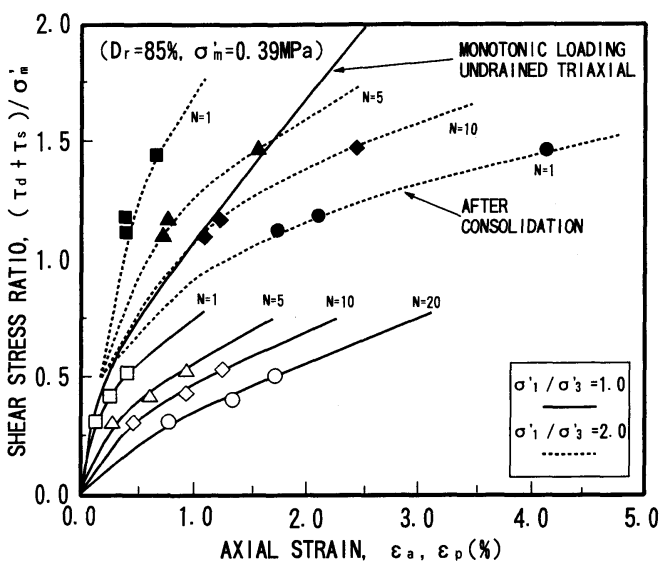

Fig.7 Shear stress ratio versus axial strain relationship at undrained cyclic loading test under isotropic and anisotropic consolidation condition $\left(\sigma^{\prime} \mathrm{m}=\right.$ $0.39 \mathrm{MPa}, \sigma^{\prime}{ }_{1} / \sigma^{\prime}{ }_{3}=1.0,2.0, \mathrm{D}_{\mathrm{r}}=85 \%$ ).

みが累積するためその最大ピークひずみで定義してい る.ここでは, 絽返しせん断応力比は次式で表している.

$$
\left(\tau_{d}+\tau_{s}\right) / \sigma_{m}^{\prime}
$$

ここで, $\tau_{\mathrm{d}}$ : 繰返しせん断応力, $\tau_{\mathrm{s}}$ : 初期せん断 応力, $\sigma_{\mathrm{m}}^{\prime}$ : 初期有効平均主応力である.

Fig.3に繰返し非排水試験の応力, ひずみ, 間隙水圧 の時刻歷, Fig.4に有効応力経路の一例を示す.

時刻歴を見ると，等方圧密の場合，繰返し載荷により ひずみ振幅が増大しながら残留ひずみは伸張側に進行 する傾向を示している. また, 間隙水圧も繰返し載荷に 伴い上昇し, その最大值は比較的初期の時点で拘束圧に 対して $100 \%$ 近くに達し，その後はほぼ一定值（間隙水 圧振幅）を保っており, 液状化のようなひずみの急増は 見られない. Fig.3 は等方圧密の場合のみを示している が, 異方圧密により初期せん断応力を加えた場合は, ひ ずみはある時点で伸張側の振幅の増加が止まり, その後 はほぼ一定振幅のまま軸ひずみが圧縮側に進行する傾 向にある. また, 間隙水圧は等方圧密の場合と同様 100\%近くに達している.

有効応力径路は間隙水圧の上昇に伴い平均有効応力 の減少側に移動し, 最終的に破壊線に沿ってループを描 いており, 密な砂で見られる挙動と同じである.

今回の試験で明らかになったロック材料の非排水繰 返しせん断特性を以下のようにまとめる.

\section{a)ひずみ発生特性}

Fig.5 に繰返し回数と発生ひずみ量の関係を示す. 繰 返し回数の増加に伴いひずみも増加しているが, 100 回 程度の繰返しでは緩詰め砂に見られるような液状化に は至っていない. ただし, せん断応力比が大きい場合に 


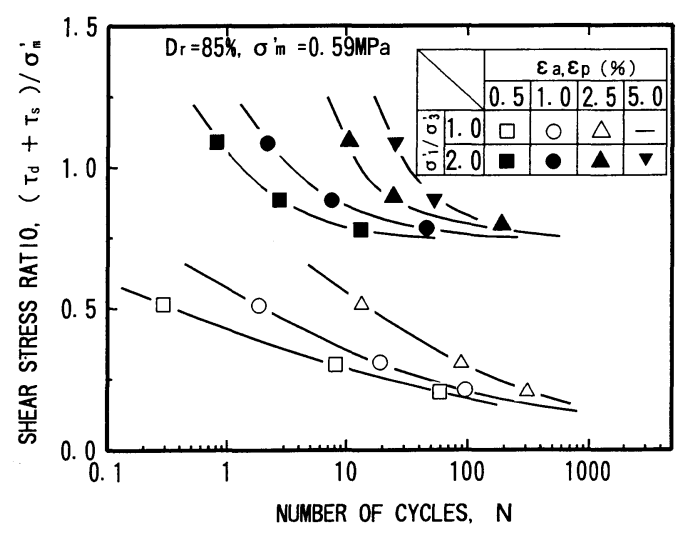

Fig.8 Shear stress ratio versus number of cyclic loading relationship at undrained cyclic loading test with isotropic and anisotropic consolidation conditions.

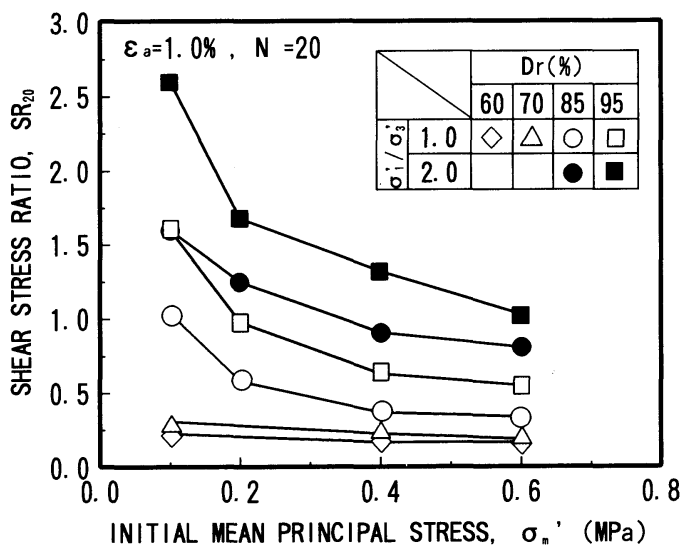

Fig.9 Shear stress ratio versus initial mean principal stress relationship at undrained cyclic loading test with $\sigma_{1}^{\prime} / \sigma_{3}^{\prime}=1.0,2.0$ and $D_{r}=60 \%, 70 \%, 85 \%$ and 95\%.

Fig.5 のようなひずみの急速な進行が見られる. 異方圧 密の Figs.5(b), 5(c)で軸ひずみが $5 \%$ に達しているもの は, 繰返し載荷に伴い供試体上端とキャップとの密着が 悪くなることによる, 伸張側のネッキングが原因と考え られる.

\section{b)間隙水圧発生特性}

Fig.6 にひずみと間隙水圧比の関係を示す. ひずみの 増加に伴い間隙水圧比 $\left(\Delta u / \sigma^{\prime}{ }_{3}\right)$ も上昇し, ひずみが 1.0\%程度でほぼピークに達しており，その後はほぼ一 定値のままでひずみだけが増大している. 間隙水圧比の 最大值は等方圧密, 異方圧密にかかわらず 0.9〜 1.0で, 拘束圧が大きいほど 1.0 に近づく傾向にある. 飽和砂に よる試験で, 間隙水圧の発生特性はせん断中の主応力の 反転の有無によって異なり, 異方圧密による初期せん断

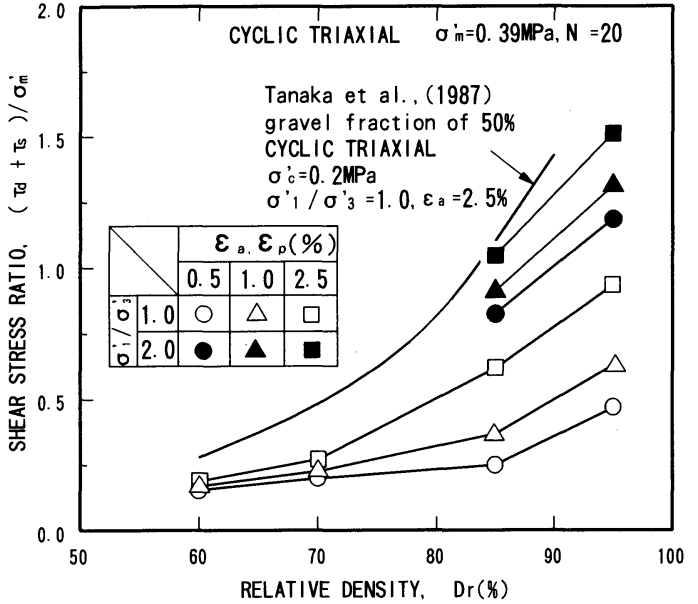

Fig.10 Shear stress ratio versus relative density of rockfill material relationship at undrained cyclic loading test with $\sigma_{1}^{\prime} / \sigma_{3}^{\prime}=1.0,2.0$.

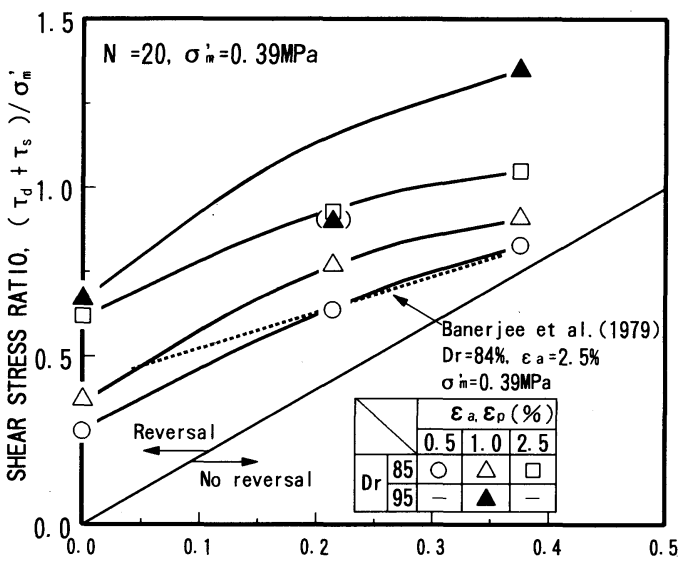

INITIAL SHEAR STRESS RATIO, $T_{\mathrm{s}} / \sigma_{\mathrm{m}}^{\prime}$

Fig.11 Shear stress ratio versus initial stress ratio relationship at $\mathrm{D}_{\mathrm{r}}=85 \%$ and $95 \%$.

応力が大きく主応力の反転のない場合の間隙水圧比は 小さくなる（兵動ら 10)によると密詰め砂で 0.3〜0.5 で ある. ) . 本研究では, 主応力比 2.0 の異方圧密でも, 間隙水圧比は 0.9 以上になっている.

\section{c)応力・ひずみ特性}

ある繰返し回数での繰返しせん断応力比と軸ひずみ の関係を Fig.7 に示す. 等方圧密と異方圧密 $\left(\sigma^{\prime}{ }_{1} / \sigma_{3}{ }_{3}\right.$ =2.0）を比較すると, 同じひずみに達するのに必要な繰 返しせん断応力比は異方圧密の方が 2 倍程度以上大き くなっている. 密な砂では一般に, 所定のひずみに達す るのに必要な繰返しせん断応力比は, 初期せん断応力が 大きい程大きくなり（例えば谷口ら 11)），これは本論文 の傾向に一致している. Fig.7には拘束圧 $0.39 \mathrm{MPa}$ ，等 


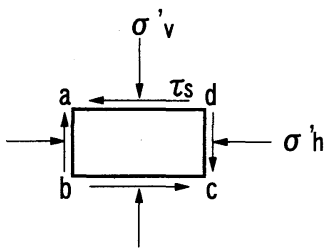

STRESS BEFORE EARTHQUAKE

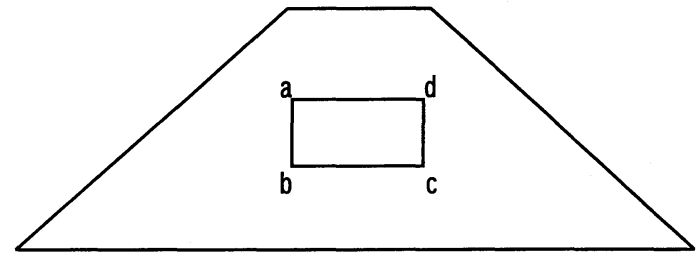

EARTHQUAKE MOTION

Fig.12 Stress and strain condition inside the embankment dam body.
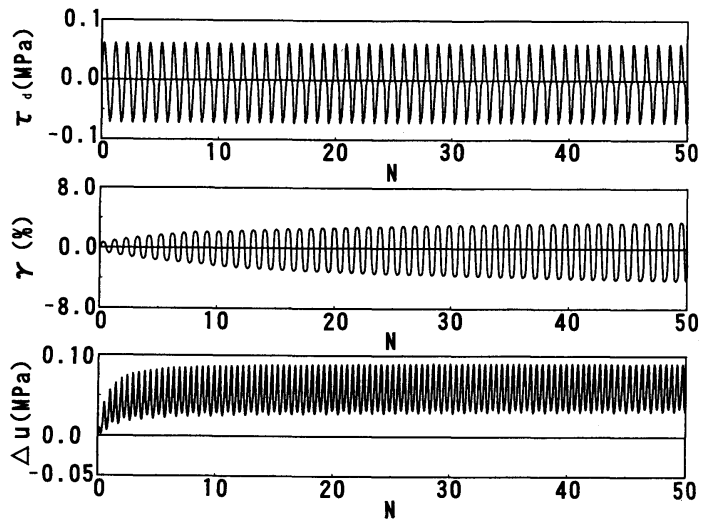

Fig.13 Time histories of shear stress, porewater pressure and shear strain at cyclic torsional simple shear $\operatorname{test}\left(\sigma_{\mathrm{m}}^{\prime}=0.1 \mathrm{MPa}, \sigma^{\prime}{ }_{1} / \sigma^{\prime}{ }_{3}=1.0, \mathrm{D}_{\mathrm{r}}=85 \%\right)$.

方圧密状態の非排水単調載荷試験のせん断応力比と軸 ひずみの関係を併せて示している.この単調載荷試験に おいて静的強度 (最大せん断応力比) を与える軸ひずみ は 6\%を越えている.等方圧密の繰返し載荷試験結果は, 非排水単調載荷試験によるせん断応力比よりも全体に 小さくなっている.一方, 非排水単調載荷試験および非 排水繰返し載荷試験（ただし異方圧密 $\sigma^{\prime}{ }_{1} / \sigma^{\prime}{ }_{3}=2.0$ ）を 比べると, 繰返し載荷試験において $\mathrm{N}=5 \sim 10$ のとき, 両者は同じせん断応力比 $\left(\left(\tau_{\mathrm{d}}+\tau_{\mathrm{s}}\right) / \sigma_{\mathrm{m}}=1.25\right)$ で, ほぼ同じ軸ひずみ（1.5\%）を生じている。つまり非排 水強度を規定するひずみを $1.5 \%$ としたときには，単調 載荷試験の結果は異方圧密の繰返し載荷試験の結果の $\mathrm{N}=5 \sim 10$ に相当する.

\section{d)重的強度特性}

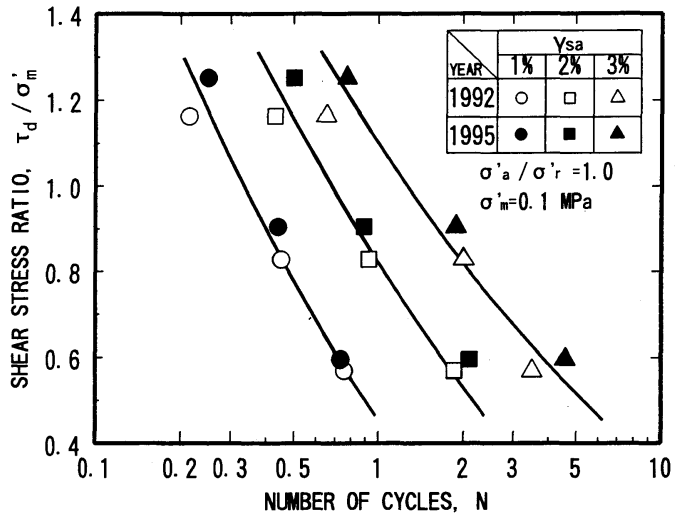

Fig.14 Undrained cyclic torsional simple shear test.
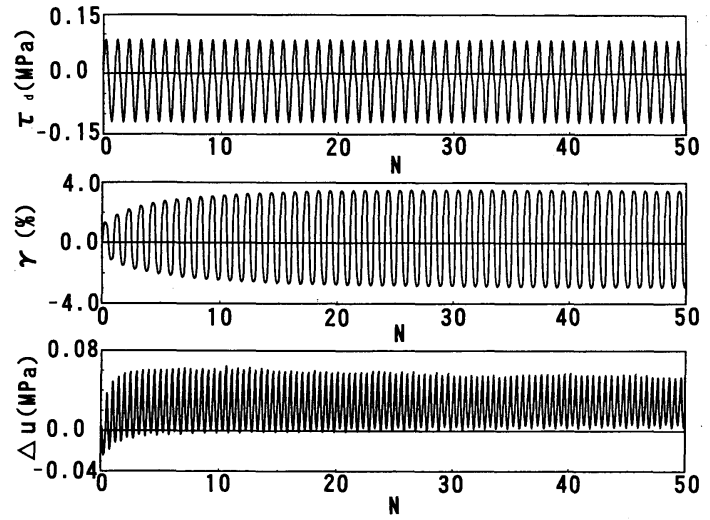

Fig.15 Time histories of shear stress, porewater pressure and shear strain at cyclic torsional simple shear test under anisotropic consolidation condition $\left(\sigma_{\mathrm{m}}^{\prime}\right.$ $=0.1 \mathrm{MPa}, \sigma^{\prime}{ }_{1} / \sigma^{\prime}{ }_{3}=1.7, \mathrm{D}_{\mathrm{r}}=85 \%$ ).

Fig.8は，軸ひずみ $\varepsilon{ }_{\mathrm{a}}=0.5,1.0,2.5,5.0 \%$ に達したと きの繰返しせん断応力比曲線であり, 繰返しせん断応力 比と繰返し回数 $\mathrm{N}$ との関係を示したものである. 繰返 し回数が多いほど，また規定ひずみが小さいほど, 繰返 しせん断応力比は小さくなっている. また, 異方圧密の せん断応力比曲線は, 圧縮・引張の交番応力となる応力 反転の境界線 $\left(\sigma_{1}{ }_{1} / \sigma_{3}{ }_{3}=2:\left(\tau_{\mathrm{d}}+\tau_{\mathrm{s}}\right) / \sigma_{\mathrm{m}}=0.75\right)$ に漸近する傾向が見られる.さて, 等方圧密状態と異方 圧密状態を比較すると繰返しせん断応力比は, 異方圧密 状態の方が $2 \sim 3$ 倍程度大きくなっている.

Fig.9 は繰返しせん断応力比曲線から 20 回の繰返し 回数で, 所定のひずみ（ここでは軸ひずみが $1 \%$ ) に達 するときの繰返しせん断応力比 $\mathrm{SR}_{20}$ を求め, 相対密度 $60 \%, 70 \%, 85 \%$ と $95 \%$ につて初期平均主応力との関 係を示したものである. 相対密度 $85 \%$ と 95\%について は繰返しせん断応力比は, 等方および異方圧密のいずれ も相対密度の高い方が 1.5 2.0 倍強くなっている. ま 


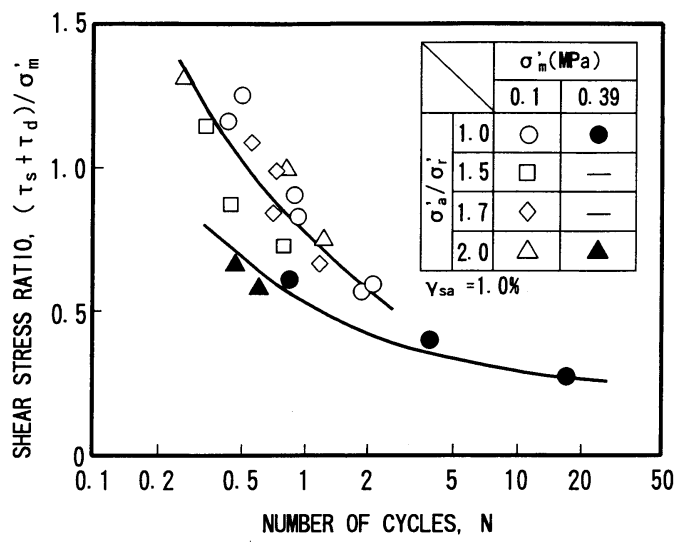

Fig.16 Shear stress ratio versus number of cyclic loading relationship under isotropic and anisotropic consolidation condition.

た, 図から繰返しせん断応力比は, $\sigma^{\prime}{ }_{\mathrm{m}}$ が低くなる程大 きく, 拘束圧の依存性がある．しかしながら，相対密度 が比較的低い $60 \%, 70 \%$ では繰返しせん断応力比は低く， しかも拘束圧の依存性も非常に小さい。このことは, 柚 木ら 12)が密な砂について繰返しせん断応力比の拘束圧 依存性を報告しているように, 単調載荷試験による破壊 強度の拘束圧依存性と同様, 粒子間接点で生じる破砕に よる粒子間摩擦角の減少が一因として考えられる.

Fig.10 は繰返しせん断応力比と相対密度の関係を示 したものである. 相対密度 85, 95\%の試験については， 等方圧密の場合, どの軸ひずみレベルにおいても密度の 増加に伴う繰返しせん断応力比の増分は, ほぼ同じであ る. 異方圧密では, $\varepsilon{ }_{\mathrm{a}}=2.5 \%$ でせん断応力比を比べる と, 密度の増加に伴う繰返しせん断応力比増分は著しい。 相対密度が 60,70\%については, 密度の増加に伴う絽返 しせん断応力比の増加は少なく, 繰返し回数 20 回で所 定のひずみに達する繰返しせん断応力比の差も少ない. 今回使用している材料は角磷材料であり, 相対密度が高 い場合粒子間の噛み合わせ効果が大きいが, 低い相対密 度ではその効果が小さいために繰返しせん断応力比に 差が表れなかったと考えられる. Fig.10には参考のため 砂啋 13)の結果を記入してある.

Fig.11 は, 異方圧密すなわち初期せん断応力による絽 返しせん断応力比への影響を見たもので, 相対密度の高 い（ $\mathrm{D}_{\mathrm{r}}=85 \%$ 以上）ロック材料では異方圧密時の主応力 比（初期せん断応力）が大きいほど繰返しせん断応力比 も大きくなる傾向を示している. 同様の関係は, 粗粒材 料では保田ら 14)が報告している.砂については既に多く の研究 15) 19)で初期せん断応力の影響を取り上げており, 軟化挙動を示さない高い相対密度では初期せん断応力 の増加にともない繰返しせん断応力比が増加すると報 告されている.いま， $\varepsilon_{\mathrm{a}}=1.0 \%$ に着目すると相対密度

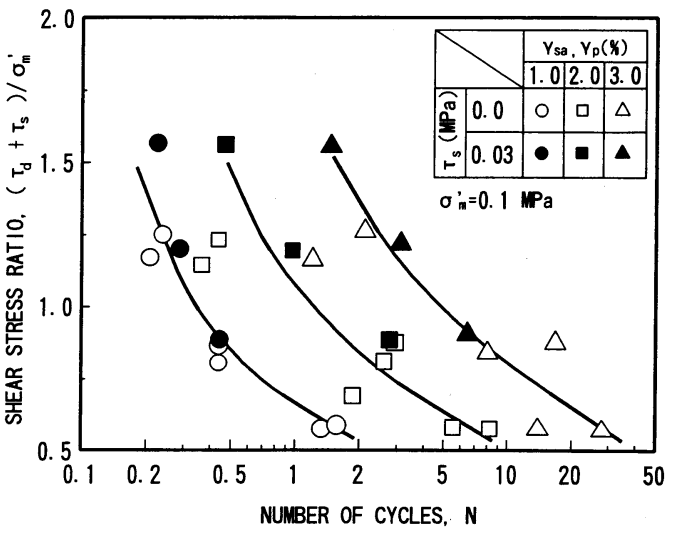

(a) $\sigma_{\mathrm{m}}^{\prime}=0.1 \mathrm{MPa}$.

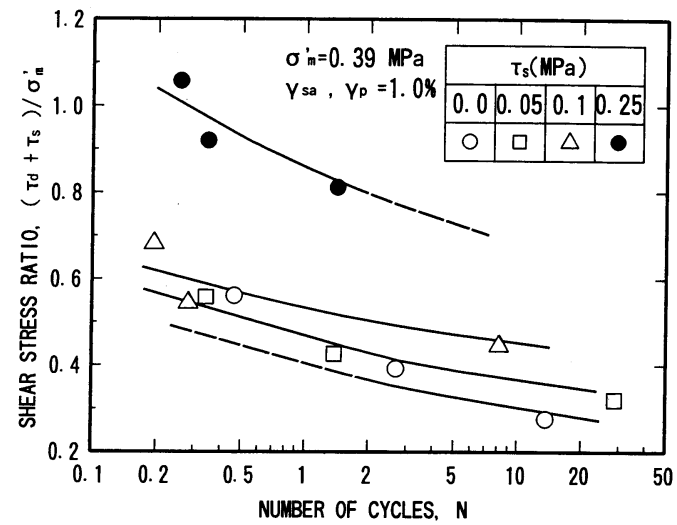

(b) $\sigma_{m}^{\prime}=0.39 \mathrm{MPa}$.

Fig.17 Effect of initial shear stress to relationship between shear stress ratio and number of cyclic loading.

が大きい程綝返しせん断応力比も大きくなっており, 全 体的に上に凸の曲線を呈している．同図には Banerjee, et al. 6)が円礫材料を用いた結果も示してあるが, 同一条 件の今回の試験結果よりも低くなっている. 主たる要因 としては,ここでは角礫材料を用いており粒子形状の相 違による粒子間のかみ合わせ程度の差が現れたものと 考えられる。

\section{（2）絽返しねじり単純せん断試験による動的強度特性}

実際のフィルダム堤体の地震時における応力・ひずみ 状態を考えると，地震による不規則な絽返し荷重により， 堤体内ではせん断応力が増減し,これは主応力方向が変 化する単純せん断変形で近似される(Fig.12 参照).これ に対して, 前述の絽返し三軸試験の場合, 主応力方向は 水平と鉛直に固定され軸対称変形が繰返される状態で あることから，実際のひずみ状態と異なっている．原位 置の応力状態を室内でより良く再現できる試験として は，繰返しねじり単純せん断試験がある.

等方圧密条件のねじりせん断試験におけるせん断応 


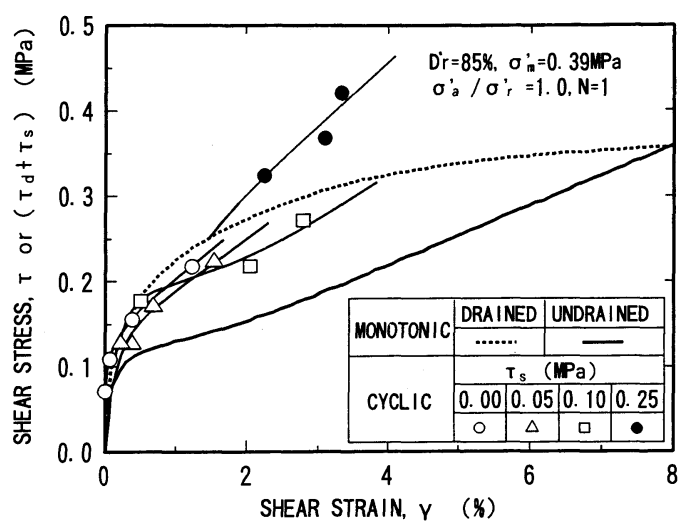

(a) $\mathrm{N}=1$.

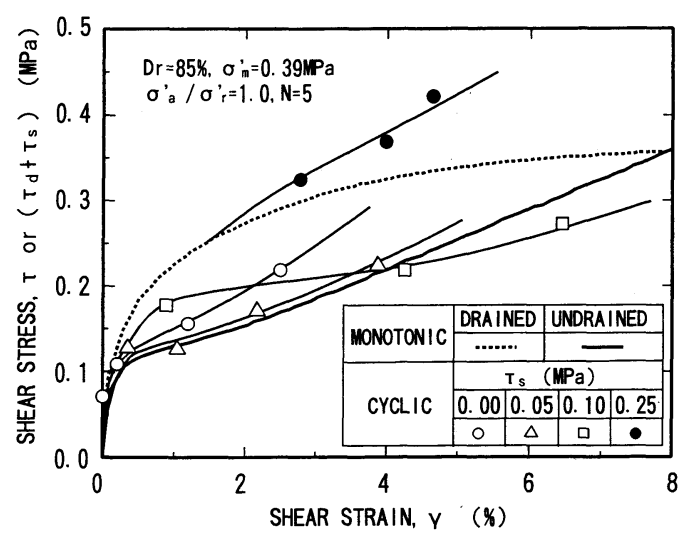

(b) $\mathrm{N}=5$.

Fig.18 Comparison of cyclic and monotonic torsional simple shear tests $\left(\sigma_{\mathrm{m}}^{\prime}=0.39 \mathrm{MPa}\right)$.

力・間隙水圧・せん断ひずみの時刻歴を Fig.13に示す. 過剩間隙水圧が繰返し回数 $2 \sim 3$ 回で最大値を示し, 有 効応力が 0 近くになるが, 供試体はその構造を失うこと なく, せん断ひずみがゆっくりと増加している. 等方圧 密の三軸試験とは異なり,一方向へ残留するひずみは殆 どゼロである.

大型のねじり単純せん断試験を用いてロック材料の 動的強度特性を検討した事例は過去にない. まず, 本研 究では試験の再現性を確認する目的で同一条件の供試 体により繰返し載荷試験を害施した。Fig.14は，有効平 均主応力 $\sigma_{m}{ }_{m}=0.1 \mathrm{MPa}$ の等方圧密状態で 3 種類の繰返 しせん断応力比について 1992 年と 1995 年に 1 供試体 づつ繰返し載荷試験を行った結果であるが, 良く一致し ている.

フィルダム堤体内の応力は, 埋設された土圧計によれ ば主応力比 $\sigma^{\prime}{ }_{1} / \sigma^{\prime}{ }_{3}$ が 1.0 2.0の範囲に分布しており, 内部ほど異方性が強い状態にある.これらの応力状態に 対して地震時にせん断力が絽返し作用することになる. 圧密応力比 $\sigma_{1}^{\prime} / \sigma_{3}^{\prime}=1.7$ の異方圧密時の時刻歴を Fig.15

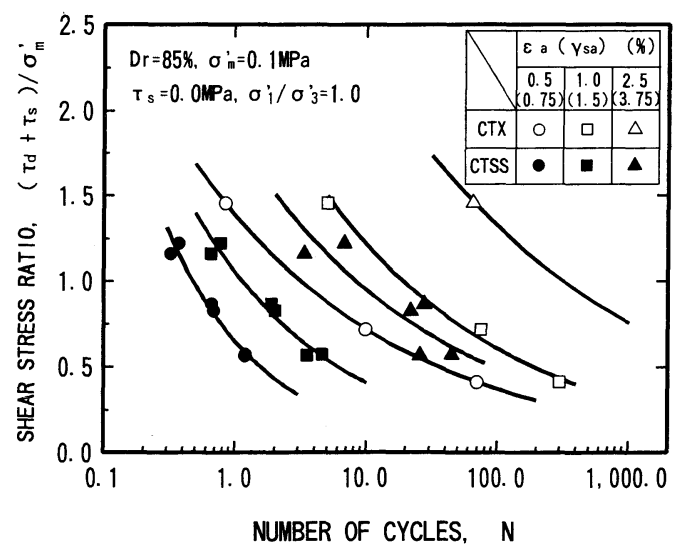

(a) $\sigma_{m}^{\prime}=0.1 \mathrm{MPa}$.

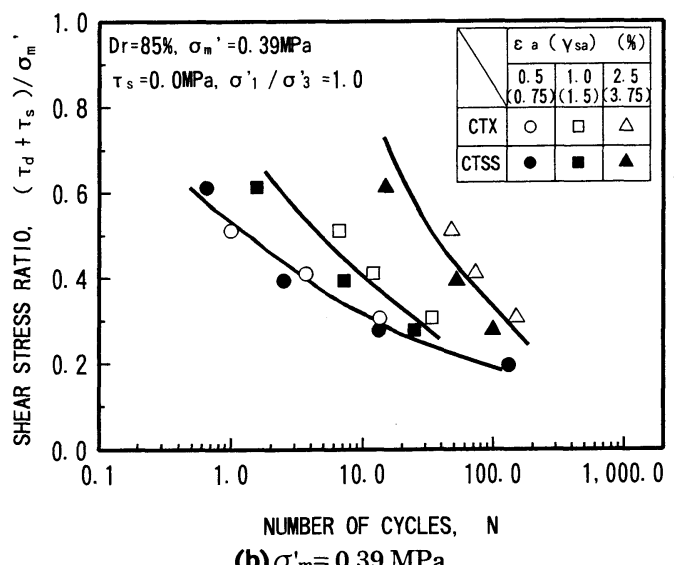

Fig.19 Comparison of cyclic and triaxial and torsional simple shear tests.

に示す. せん断ひずみは, 等方圧密の場合と異なり, 漸 増する傾向にはない. また, この試験は $\sigma_{\mathrm{m}}^{\prime}=0.1 \mathrm{MPa}$, $\sigma_{\mathrm{r}}^{\prime}=0.08 \mathrm{MPa}$ であるが, 間隙水圧は最大で $0.064 \mathrm{MPa}$ となっている.

圧密応力比 1.0 2.0 の範囲について, 1.0\%の片振幅 ひずみに着目した際の繰返しせん断応力比と繰返し載 荷回数の関係を Fig.16 に示す. いずれの圧密応力比に おいても同一繰返しせん断応力比に着目した場合, $\sigma_{\mathrm{m}}^{\prime}$ $=0.39 \mathrm{MPa}$ の試験值が少ない回数で片振幅せん断ひず み $1.0 \%$ に達しており，拘束圧依存性が認められる。 た, 圧密応力比の影響は, $0.39 \mathrm{MPa}, 0.1 \mathrm{MPa}$ いずれの 平均主応力においてもほぼ同じ回数で所定のひずみに 達しており，顕著ではない。

次に初期せん断応力の影響を示すが, 今回の研究にお いて試験時の初期せん断応力は, 予じめ単調載荷試験を 行い, 破壊せん断応力未満となるように設定している.

$\sigma_{\mathrm{m}}^{\prime}=0.1 \mathrm{MPa}$ についてピークせん断ひずみ $\gamma \mathrm{p}($ ただ し, 初期せん断応力 $\tau$ s が 0 の場合は片振幅せん断ひず 


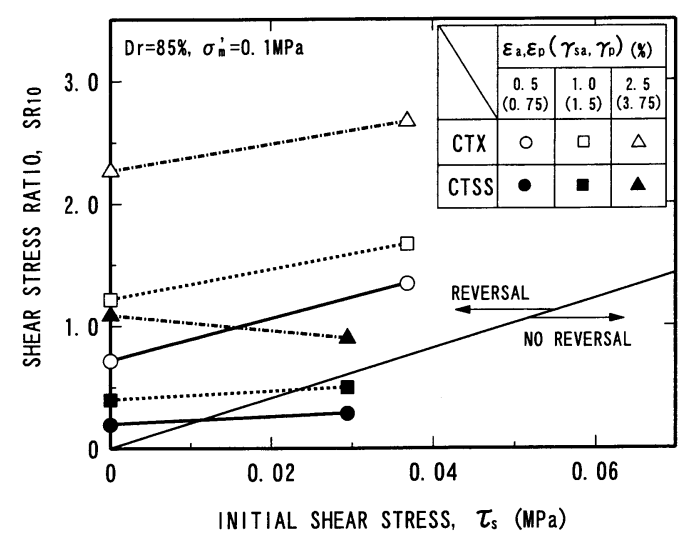

(a) $\sigma_{m}^{\prime}=0.1 \mathrm{MPa}$.

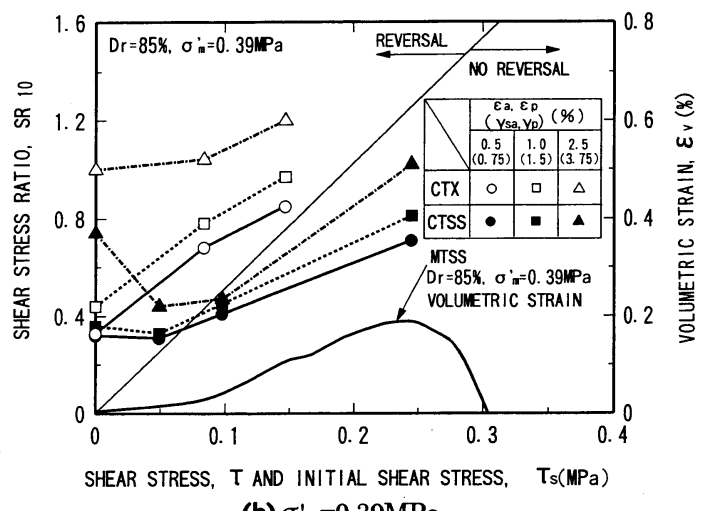

(b) $\sigma_{\mathrm{m}}^{\prime}=0.39 \mathrm{MPa}$.

Fig.20 Comparison of relationship between $\mathrm{SR}_{10}$ and initial shear stress of cyclic triaxial and torsional simple shear tests.

み $\gamma$ sa である.)をパラメータとして初期せん断応力の 影響を示したのが Fig.17(a)である. 各 $\gamma_{\mathrm{p}}$ に着目した繰 返しせん断応力と繰返し回数に及ぼす $\tau \mathrm{s}_{\mathrm{s}}$ の影響は次に 示す $\sigma_{\mathrm{m}}^{\prime}=0.39 \mathrm{MPa}$ の場合よりも小さい. Fig.17(b)に $\sigma^{\prime}{ }_{\mathrm{m}}=0.39 \mathrm{MPa}$ について, 初期せん断応力 $\tau \mathrm{s}$ をパラメ 一タとし, 繰返しせん断応力比とピークせん断ひずみ $\gamma_{\mathrm{p}}$ が 1.0\%に達したときの繰返し載荷回数の関係を示 す. $\tau_{\mathrm{s}}<0.1 \mathrm{MPa}$ では, $\tau_{\mathrm{s}}$ とせん断応力比 $\left(\tau_{\mathrm{d}}+\tau_{\mathrm{s}}\right)$ $/ \sigma_{\mathrm{m}}^{\prime}$ の関係は明瞭ではないが, $\tau \mathrm{s}=0.25 \mathrm{MPa}$ の場合に は $\tau_{\mathrm{s}}<0.1 \mathrm{MPa}$ の場合に比べ, 明らかにせん断応力比が 増加している. Fig.18は, 単調載荷試験結果と繰返し載 荷試験結果を示す. 繰返し載荷試験は載荷回数は 1 およ び 5 回である. 載荷回数が 1 回の場合 $\tau$ s が $0.1 \mathrm{MPa}$ ま では, $\tau{ }_{s}$ の増加に対し, 繰返し載荷試験の応力・ひず み関係は排水単調載荷試験の応力に同じか下回ってい るが, $\tau_{\mathrm{s}}=0.25 \mathrm{MPa}$ では排水単調載荷試験の応力を上 回っている. また, 載荷回数が 5 回になると, 応力・ひ ずみ関係は排水単調載荷試験よりも非排水単調載荷試 験結果に近付いている.このときも $\tau \mathrm{s}=0.25 \mathrm{MPa}$ では
排水単調載荷試験の応力を上回っている.このことは, せん断試験時の供試体の体積膨張(ダイレイション)によ り説明される. すなわち， $\tau{ }_{\mathrm{s}}$ が $0.1 \mathrm{MPa}$ 以下では供試 体は収縮する領域であるため, 発生するひずみが大きい のに対し, $\tau_{\mathrm{s}}=0.25 \mathrm{MPa}$ はダイレイションを生じる状 況にあり, 発生するひずみが小さいことによると考えら れる.

\section{(3)三軸試験とねじり単純せん断試験の比較}

ねじり単純せん断試験は, 原位置の応力・ひずみ関係 を他の試験方法に比べて良く再現していると考えられ る. しかしながらロック材料等のいわゆる粗粒材料を扱 う場合には, 試験が大がかりになることから多用されて いないのが現状である.一方，三軸試験は，原位置の応 力・ひずみ状態を忠実に再現していないものの, 試験自 体がねじり単純せん断試験に比べ簡易である.以上のこ とから，三軸試験が数多く実施されているが，ここでは 動的強度特性に関して試験方法の違いによる影響を明 確にする.

繰返し三軸試験における繰返しせん断応力比から, 原 位置地盤の応力状態に近いねじり単純せん断試験によ る繰返しせん断応力比は補正係数によって関連付けら れる. 非排水試験において, ポアソン比 ことから, 次式をもとにせん断ひずみ $\gamma$ と軸ひずみ $\varepsilon a$ を対比した。

$$
\gamma=(1+\nu) \cdot \varepsilon_{\mathrm{a}}
$$

Figs.19(a)，19(b)は三軸試験(CTX)とねじり単純せん 断試験(CTSS)のせん断応力比曲線を示したもので, $\sigma^{\prime}{ }_{\mathrm{m}}$ $=0.39 \mathrm{MPa}$ の等方圧密では若干下回るものの三軸試験 のせん断応力比とほぼ等しくなっている. Ishihara and Yasuda ${ }^{20)}$ は，緩詰めの富士砂を用いた三軸試験とねじ りせん断試験の結果は一致するとしている.ただし, 今 回の研究において $\sigma_{\mathrm{m}}^{\prime}=0.1 \mathrm{MPa}$ では, ねじり単純せん 断試験の結果が三軸試験の結果を下回っている.

次に, 10 回の繰返し回数で所定のひずみに達するの に要するせん断応力比 $\mathrm{SR}_{10}$ と初期せん断応力 $\tau{ }_{\mathrm{s}}$ の関 係を Figs.20(a), 20(b)に示す. $\sigma_{\mathrm{m}}^{\prime}=0.1 \mathrm{MPa}$ では, 三軸 試験(CTX)はいずれのピークひずみについても初期せ ん断応力が作用すると $\mathrm{SR}_{10}$ が増加している。一方，ね じり単純せん断試験(CTSS)の場合, 初期せん断応力の 作用により $\mathrm{SR}_{10}$ が僅かに増加するが大きなひずみでは 減少している. 一方, $\sigma^{\prime}{ }_{m}=0.39 \mathrm{MPa}$ では, ねじり単純 せん断試験の $\mathrm{SR}_{10}$ は, 初期せん断応力 $\tau{ }_{\mathrm{s}}$ の作用によ $\eta \tau_{\mathrm{s}}=0$ の時に比べ一旦減少するが $\tau_{\mathrm{s}}$ の増加に伴い, 増加する傾向にあり, $\tau_{\mathrm{s}}=0.25 \mathrm{MPa}$ の場合特に著しい. Fig.2O(b)には， $\sigma_{\mathrm{m}}^{\prime}=0.39 \mathrm{MPa}$ における単調載荷のねじ り単純せん断試験(MTSS)の体積ひずみ $\varepsilon$ v とせん断応 


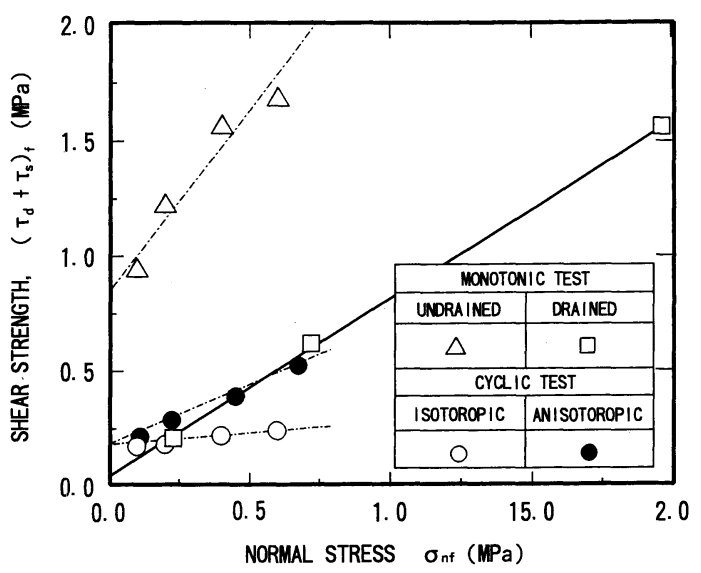

Fig.21 Comparison of strength from cyclic and monotonic loading tests (triaxial).

力ての関係も併せて示してある. せん断応力により, 体 積が収縮し, せん断応力が $0.25 \mathrm{MPa}$ 付近から体積の膨 張に転じている.すなわち, 供試体の体積ひずみが膨張 に転じるまで, 初期せん断応力が作用した場合, 大きな $\mathrm{SR}_{10}$ が期待される. 飽和砂について, 三軸試験とねじ り単純せん断試験結果の比較検討が Tatsuoka et al. ${ }^{21)}$,

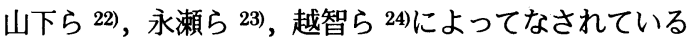
が, せん断応力比の大小関係は明確ではない. しかしな がら, ロック材料では, 平均主応力・初期せん断応力の 大小にかかわらず，ねじり単純せん断試験の結果は, 変 形量の観点から強度を定める場合, 三軸試験の結果にほ ぼ同じか，下回ると考えられる.

\section{(4)静的強度と功的強度の比较}

強度を定めるとき, 対象とするせん断面の仮定の仕方 でその大きさが変わってくるが, Fig.21ではせん断強度 として, 主応力の方向に対して $45^{\circ}$ 面上の応力をもって 動的強度と静的強度との比較を行った. なお, 動的強度 は三軸試験によって求めたものであり, 繰返し回数 20 回かつ規準ひずみ $2.5 \%$ の值で，メンブレンコンプラ イアンスの影響を補正（一律 10\%減）したものである. 一方, 静的強度はひずみ $15 \%$ 以内でのピーク応力で定 めている.

単調載荷試験による静的非排水強度に比べ動的強度 は小さいことが分かる.フィルダムの設計 2)ではロック 材料は静的排水強度が用いられており, 動的強度と静的 排水強度を比較すると規定せん断面上の垂直応力が $0.49 \mathrm{MPa}$ 以下では異方圧密での動的強度の方が大きく なった.

動的強度を規定するひずみ量のとり方には, 決まった 判断基準はなく, 構造物の安定・不安定の境となる変形 量から定められるものではあるが, 今回の場合, 繰返し
載荷試験では, 試験装置の機構上, 測定可能なひずみ量 が制限されていたため, データの信頼性から基準ひずみ $2.5 \%$ で整理した. したがって, フィルダムなどの安定 を考える上で，5.0\%程度のひずみを許容すると，動的 強度はさらに大きくなるので, 異方圧密の動的強度が排 水強度を上回る傾向は, さらに明確になると推定される。

\section{4. 結 論}

ロックフィルダムの耐震設計の実務では, 材料の強度 は三軸試験による排水強度（静的強度）が使われてきた。 今回三軸試験およびねじり単純せん断試験による一連 の非排水繰返し載荷試験を実施した. その結果締固めた ロック材料は繰返し載荷に対して液状化のようにひず みは急増せず, 拘束圧の小さな領域では動的強度は静的 強度を上回っており地震時に強度を失うことはなく, 実 務で静的強度を使用することは安全側の設計になって いることがわかった. しかしながら, 原位置の応力ひず み状況を再現していると考えれるねじり単純せん断試 験では, 動的強度は三軸試験のそれを若干下回っており， 静的強度とのさらなる比較検討が必要である.

以下に, 今回実施した良く締固めたロック材料の繰返 し載荷試験の結果を示す.

(1)非排水繰返し載荷試験では, 繰返し回数の増加に伴い ひずみが増大し，間隙水圧は 90\%〜100\%近くまで急激 に上昇しているが,液状化のような flow failure は起こ らない。

(2)密なロック材料の非排水三軸繰返し試験では, 等方圧 密の場合累積ひずみは伸張側に進行する.

(3)密なロック材料の応力〜ひずみ特性は載荷条件によ らず定性的には密な砂の特性と類似している.

(4)非排水繰返し試験では, 絽返しにより間隙水圧が上昇 し,ひずみも増大する. 所定のひずみに達するのに必要 なせん断応力比は, 相対密度が大きい程, 平均主応力が 小さい程, 初期せん断応力が大きい程大きな值を示し, その傾向は定性的には密な砂に関する報告に一致して いる.

(5)ねじり単純せん断試験におけるせん断応力比は平均 主応力・初期せん断の大きさに依らず三軸試験のそれを 下回る傾向にある.

〔6ねじり単純せん断試験の場合, 所定のひずみに達する のに必要なせん断応力比は, 平均主応力が小さい程大き い. また, 等方圧密時のせん断応力比は, 異方圧密時の それよりも大きい傾向にある.さらに, 初期せん断応力 が供試体の体積膨張を生じさせる場合, せん断応力比の 増加は著しい。

なお, 本研究は筆者らが建設省土木研究所ダム部フィ ルダム研究室在籍時に取りまとめられたもので, 同研究 
室の関係各位に謝意を表します。

付 録

$\mathrm{C}_{\mathrm{RM}}$;メンブレン貫入に伴うメンブレン・コンプライ

アンス比

CTSS ; 繰返し載荷のねじり単純せん断試験

CTX; 繰返し載荷の三軸試験

$\mathrm{D}_{\max }$;最大粒径

$\mathrm{D}_{\mathbf{r}} ;$ 相対密度

$\mathrm{D}_{50}$;平均粒径

e ;間隙比

$\mathrm{G}_{s} ;$ 粒子の比重

MTSS;単調載荷のねじり単純せん断試験

$\mathrm{N}$; 繰返し回数

$\mathrm{SR}_{10} ; 10$ 回の繰返し回数において所定のひずみに達 するのに要するせん断応力比

$\mathrm{SR}_{20} ; 20$ 回の繰返し回数において所定のひずみに達 するのに要するせん断応力比

$\mathrm{U}_{\mathrm{c}}$; 均等係数

$\triangle \mathrm{u}$;間隙水圧

$\mathrm{w}$;含水比

$\gamma$;せん断ひずみ

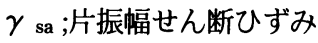

$\gamma_{\mathrm{p}} ;$ 最大ピークせん断ひずみ

$\varepsilon_{\mathrm{a}}$;軸ひずみ (単調載荷),あるいは片振軸ひずみ (繰 返し載荷)

$\varepsilon_{\mathrm{p}} ;$ 最大ピーク軸ひずみ

$\varepsilon_{\mathrm{v}} ;$ 体積ひずみ

$\varepsilon \mathrm{vm} ;$ ×ンブレン貫入量

$\nu$;ポアソン比 $\left(1-\varepsilon_{\mathrm{v}} / \varepsilon_{\mathrm{a}}\right) / 2$

$\rho_{\mathrm{d}}$; 供試体の乾燥密度

$\sigma_{1}^{\prime}$; 有効最大主応力

$\sigma^{\prime}{ }_{3}$; 有効最小主応力

$\sigma_{\mathrm{a}}^{\prime}$; 有効軸応力

$\sigma_{\mathrm{r}}^{\prime} ;$ ねじり単純せん断試験の有効側応力

$\sigma_{\mathrm{m}}^{\prime}$; 有効平均主応力 $=\left(\sigma^{\prime}{ }_{1}+2 \sigma^{\prime}{ }_{3}\right) / 3$

$\tau_{\mathrm{d}}, \sigma_{\mathrm{d}} / 2$; 繰返しせん断応力

$\tau s$;初期せん断応力

\section{参考文献}

1) Jennings, P.C.: Engineering features of the San Fernando Earthquake, February 9, 1971, Earthquake Engineering Research Laboratory, California Institute of Technology, 1971.

2) 建設省河川局監修 : 建設省河川砂防技術基準（案）設計 編 [ I ] , (社)日本河川協会編, 山海堂, pp.201-206, 1985.

3）松本徳久, 安田成夫, 山邊建二 : フィルダムに作用する 地震力およびその簡易推定法, 土木学会論文集, No.459
/ I -22, pp.103-112. 1993.

4) ロックフィルダム耐震調査委員会 : ロックフィルダムの 耐震設計(案)，(財)国土開発技術センター, 1992.

5) Yasuda, N. and Matsumoto, N.: Dynamic deformation characteristics of sands and rockfill materials, Canadian Geotechnical Journal, Vol.30, No.4, pp.747-757, 1993.

6) Banerjee, N.G., Seed, H.B. and Chan, C.K.: Cyclic behavior of dense coarse-grained materials in relation to the seismic stability of dams, UCB/EERC79/13, 1979.

7) Martin, G.R., Finn, W.D.L. and Seed, H.B.: Effects of system compliance on liquefaction tests, Proceedings of ASCE, Journal of GT, Vol.104, pp.463-479, 1978.

8) Castro, G.: Liquefaction and cyclic mobility of saturated sands, Proceedings of ASCE, Vol.101, No.GT6, pp.551-569, 1975.

9）地盤工学会 : 土質試験の方法と解説，p.430.

10）兵動正幸, 村田秀一, 安福規之, 藤井照久, 谷水秀行 : 初期せん断を受ける飽和砂の動的強度について, 第 24 回土質工学会研究発表会, pp.797-800, 1989.

11）谷口栄一, 紫田修三, 古賀泰之, 森下 義 : 繰返し荷重 による密な砂の変形・強度特性, 第 20 回土質工学会研 究発表会, pp.561-564, 1985.

12）柚木裕二, 石原研而, 関 元治, 米田吉博: 密な砂の繰 返し三軸せん断挙動に与える初期有効拘束圧の影響, 第 17 回土質工学研究発表会, pp.1649-1652, 1982.

13）田中幸久, 工藤康二, 松井家孝, 国生剛治, 久保田博 : 砂碟材の動的強度に及ぼす密度,粒度の影響, 第 22 回土 質工学会研究発表会, pp.605-606, 1987.

14）保田雅彦, 山田真一, 山下哲郎, 龍岡文夫 : 明石層砂啋 試料の繰返し非排水試験による変形・強度特性, 第 24 回土質工学研究発表会, pp.817-820, 1989.

15) Lee, $K$. and Seed, H.B.: Dynamic strength of anisotropically consolidated sand, Proceedings of ASCE, Journal of Soil Mechanics, Vol.93, pp.169-190, 1967.

16) Vaid, Y.P. and Chern, J.C.: Effect of static shear on resistance to liquefaction, Soils and Foundations, Vol.23, pp.47-60, 1983.

17) 国生剛治, 加藤 進, 嶋田光明 : 初期せん断応力を受け た密な砂の非排水繰返しせん断特性, 第 16 回土質工学 会研究発表会, pp.581-584, 1981.

18）関 真一, 松尾 修, 古賀泰之: 初期せん断を受けた飽 和砂の動的強度特性, 第 24 回土質工学会研究発表会, pp.795-796, 1989.

19）兵動正幸, 村田秀一, 安福規之, 小浪岳治, 谷水秀行 : 異方圧密砂の非排水せん断強度に及ぼす密度の影響, 第 
25 回土質工学会研究発表会, pp.747-750, 1990.

20) Ishihara, K. and Yasuda, S.: Sand liquefaction in hollow cylinder torsion under irregular excitation, Soils and Foundations, Vol.15, No.1, pp.45-59, 1975.

21) Tatsuoka, F., Ochi, K., Fujii, S. and Okamoto, M.: Cyclic undrained triaxial and torsional shear strength of sand for different sample preparation methods, Soils and Foundations, Vol.26, No.3, pp.23$41,1986$.
22）山下 聡, 土岐祥介, 三浦均也 : メンブレン貫入の影響 を考慮した非排水繰返し三軸強度とねじりせん断強度， 第 24 回土質工学会研究発表会, pp.777-780, 1989.

23）越智健三，龍岡文夫，山本博之 : ねじりせん断液状化強 度と三軸液状化強度と関係について, 第 19 回土質工学 研究発表会, pp.583-586, 1984.

24）永瀬英生, 石原研而, 篠崎友利 : 異方圧密下における砂 の繰返し中空ねじりせん断試験, 第 19 回土質工学会研 究発表会, pp.589-590, 1984.

\title{
UNDRAINED CYCLIC STRENGTH OF COMPACTED ROCKFILL MATERIAL FROM TRIAXIAL AND TORSIONAL SIMPLE SHEAR TESTS
}

\author{
Norihisa MATSUMOTO, Nario YASUDA and Ryo-ichi YOSHIOKA
}

The dynamic strength by cyclic loading testing is compared with the static strength by monotonic loading testing using triaxial and torsional simple shear tests as for cyclic number, shear strength, relative density of specimen, confining pressure and initial shear stress. The results show that during an undrained cyclic loading test, the increase in the cyclic number is accompanied by rising axial strain and a rapid buildup of the porewater pressure to between $90 \%$ and $100 \%$, but that liquefaction or flow failure does not occur. The cyclic shear stress ratio obtained from a torsional simple shear test is smaller than that obtained from a triaxial test, regardless of the mean principal stress or initial shear stress. 